\title{
Effect of vitamin D supplementation on depression treatment
}

\author{
Raphaele Teixeira Moreira (1), Lays Arnaud Rosal Lopes Rodrigues²* (D), Luciana Melo de Farias² (1), \\ Jany de Moura Crisóstomo² (D), Layanne Cristina de Carvalho Lavôr ${ }^{2}$ (D), \\ Onias de Sousa Rodrigues Filho ${ }^{3}$ ㄴ, Karoline de Macêdo Gonçalves Frota ${ }^{4}$
}

\section{INTRODUCTION}

Depression is a mental disorder that has drawn attention because of its high incidence. The World Health Organization (WHO) reported that the number of cases of depression increased by $18 \%$ between 2005 and 2015; 322 million people have depression globally, and most of them are women. In Brazil, depression affects 11.5 million people $(5.8 \%$ of the population $)^{1}$.

Depression is characterized by the impairment of the physical and mental states of an individual. Its main symptoms are constant sadness, lack of energy, irritability, anxiety, and loss of interest in activities that usually produce a feeling of pleasure, low self-esteem, and changes in sleep and appetite. For the diagnosis of depression, symptoms should persist for at least 2 weeks ${ }^{2,3}$.

Depression is also associated with serious disabilities, mortality, and medical expenses. Despite the development of biological, psychological, and environmental theories, the underlying pathophysiology of depression is still unknown and may involve several mechanisms $s^{4,5}$.

There has been a long-standing interest in the role of nutrition and its relationship to depression; some studies have shown a strong relationship between vitamin D and depression. Several dietary factors have been implicated in the development and treatment of depression. The changes in vitamin $\mathrm{D}$ receptors impact several brain neurotransmitters and, therefore, suggest a potential role of vitamin D in causing and correcting mood disorders ${ }^{6}$.

Vitamin D is involved in several brain processes, including neuroimmune regulation, neurotrophic factor regulation, neuroprotection, neuroplasticity, and brain development. Therefore, biologically speaking, this vitamin may be related to depression, and its supplementation may play an important role in the treatment of the disease $e^{7,8}$. Therefore, this study aimed to review the recent literature on the effect of vitamin $\mathrm{D}$ supplementation in the treatment of patients with depression.

\section{METHODS}

A systematic review of vitamin D supplementation in patients with depression was performed. For the guiding question, the PICO strategy was used, which represents the population (P) to be studied, the intervention (I), comparison (C), and outcome $(\mathrm{O})$. The question to be raised was whether vitamin D supplementation, compared with placebo, helps in the treatment of patients with depression. Each PICO item represents an element: $(\mathrm{P})$ patients with depression, (I) vitamin D supplementation, $(\mathrm{C})$ placebo, and $(\mathrm{O})$ improvements in patient health.

The review was carried out from September to December 2020 and included all articles published up to the time of the research retrieved from the PubMed, SciELO, and ScienceDirect databases. The following combination of descriptors was used in the search for articles: supplementation and (depression or depressive symptoms) and vitamin D registered in the Medical Subject Headings.

Original articles and randomized (RCTs) and placebo-controlled clinical trials addressing vitamin $\mathrm{D}$ supplementation

\footnotetext{
${ }^{1}$ Centro Universitário Uninovafapi, Departamento de Nutrição Clínica, Funcional e Estética - Teresina (PI), Brazil.

2Universidade Federal do Piauí, Departamento de Alimentação e Nutrição -Teresina (PI), Brazil.

${ }^{3}$ Universidade Federal do Piaú, Hospital Universitário - Teresina (PI), Brazil.

${ }^{4}$ Universidade Federal do Piauí, Centro de Ciências da Saúde, Departamento de Nutrição - Teresina (PI), Brazil.

*Corresponding author: lays_rosal@hotmail.com

Conflicts of interest: the authors declare there is no conflicts of interest. Funding: none.

Received on April 15, 2021. Accepted on May 30, 2021.
} 
in patients with depression with different clinical conditions and at different ages were included. Duplicate original articles and articles that could not be accessed were excluded. The research was registered with the Research Coordination of the UNINOVAFAPI University Center under case number $104 / 2020$.

The Preferred Reporting Items for Systematic Reviews and Meta-Analyses (PRISMA) protocol was used to ensure the quality of this study. For the quantitative analysis and risk of methodological bias, the Jadad scale was used to classify articles from 0 to 5 based on the methodological criteria and adequacy of results, and the Cochrane collaboration tool was used to classify articles with a low risk of bias, high risk of bias, and uncertain risk of bias.

\section{RESULTS}

The bibliographic research, according to the pre-established strategy, resulted in 830 articles. Of these, 46 were from the PubMed database, 784 were from ScienceDirect, and 0 were from SciELO. After the duplicate article selection and removal process, six original RCTs were identified as eligible for this systematic review. Figure 1 shows the flowchart of the search results for the sources of information and the selection and inclusion of original articles in the systematic review, according to the PRISMA protocol.

The clinical trials showed a homogeneous methodological quality based on the risk of bias assessment using the Cochrane tool (Table 1) ${ }^{9-14}$. Random generation and allocation concealment were adequately reported in $83.35 \%(5 / 6)$

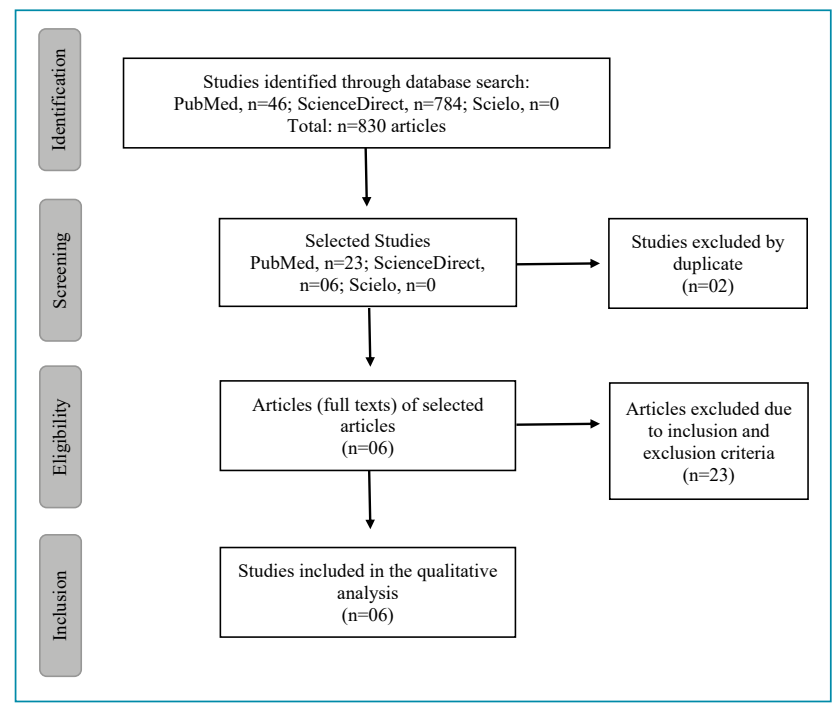

Figure 1. Flowchart for the database search and screening, eligibility, and inclusion of articles in the systematic review. of the studies; blinding of participants and professionals was reported in $100 \%(6 / 6)$ with a low risk of bias; blinding of the outcome evaluators was reported in $50 \%$ (3/6) with a low risk of bias; incomplete outcomes were reported in $66.66 \%$ (4/6) with a low risk of bias; selective outcome reporting was reported in $100 \%(6 / 6)$ with uncertain risk of bias; and other sources of bias were reported in $16.6 \%$ (1/6) with low risk of bias. Table $1^{9-14}$ presents the results of the quality assessment of the articles analyzed according to the Jadad scale. Regarding the items assessed, all articles adequately described the aspects assessed using that scale.

The data presented in Table $2^{9-14}$ integrate the results of the articles reviewed, including authors, year of publication, study sample size, dose, assessment instrument, duration of supplementation, and main outcomes. The supplemental doses of vitamin D ranged from 2,800 to 50,000 IU, and the duration of intervention ranged from 8 weeks to 2 years.

The main variable investigated was the relationship between vitamin D supplementation and depressive symptoms. Three studies showed a positive effect of supplementation on disease activity, and three studies showed no improvement in disease activity after supplementation.

\section{DISCUSSION}

Of the clinical trials present in this review, three found improvements with the use of vitamin $\mathrm{D}$ supplementation in depression symptoms: Alavi et al. ${ }^{11}$, Omidian et al. ${ }^{13}$, and Zheng et al..$^{14}$ Three other studies found no improvement: Hansen et al. ${ }^{9}$, Marsh et al. ${ }^{10}$, and Kjærgaard et al. ${ }^{12}$

Hansen et al. ${ }^{9}$ randomized patients with depression into two groups (intervention or control) in blocks of four to receive vitamin D (70 $\mu \mathrm{g}$ vitamin D3 [2,800 IU]) or placebo for 12 weeks. At baseline, 23 patients had a normal 25-hydroxyvita$\min \mathrm{D}(25(\mathrm{OH}) \mathrm{D})$ concentration $(\geq 50 \mathrm{nmol} / \mathrm{L}), 22$ had insufficiency $(<25 \mathrm{nmol} / \mathrm{L})$, and 17 had deficiency $(25-50 \mathrm{nmo}-$ $1 / \mathrm{L}$ ). At the end of the treatment, vitamin D supplementation did not reduce the symptom scores among the patients with depression. The study may not have shown significant outcome data, as they did not reach the estimated sample size and did not exclusively include patients with low vitamin $\mathrm{D}$ content.

In the study by Marsh et al. ${ }^{10}$, the participants were allocated in a 1:1 ratio. The participants received 5,000 IU vitamin D3 (cholecalciferol) capsules daily or placebo for 12 weeks. The mean serum $25(\mathrm{OH}) \mathrm{D}$ concentration increased by $9.9 \pm 8.2$ $\mathrm{ng} / \mathrm{mL}$ in vitamin $\mathrm{D}$ in the supplemented group and by $1.3 \pm 4.3$ $\mathrm{ng} / \mathrm{mL}$ in the placebo group for 12 weeks. At the end of the experiment, there was no improvement in the symptoms of depression with treatment relative to placebo. The absence of 
Table 1. Analysis of methodological quality and risk of bias according to the Cochrane collaboration and Jadad scale.

\begin{tabular}{|c|c|c|c|c|c|c|}
\hline \multicolumn{7}{|c|}{ Cochrane tool } \\
\hline Variables & Hansen et al. ${ }^{9}$ & Marsh et al. ${ }^{10}$ & Alavi et al. ${ }^{11}$ & $\begin{array}{l}\text { Kjaergaard } \\
\text { et al. }{ }^{12}\end{array}$ & $\begin{array}{l}\text { Omidian } \\
\text { et al. }{ }^{13}\end{array}$ & Zheng et al. ${ }^{14}$ \\
\hline $\begin{array}{l}\text { Random Sequence } \\
\text { Generation }\end{array}$ & $\begin{array}{l}\text { Low risk of } \\
\text { bias }\end{array}$ & $\begin{array}{l}\text { High risk of } \\
\text { bias }\end{array}$ & $\begin{array}{l}\text { Low risk of } \\
\text { bias }\end{array}$ & $\begin{array}{l}\text { Low risk of } \\
\text { bias }\end{array}$ & $\begin{array}{l}\text { Low risk of } \\
\text { bias }\end{array}$ & $\begin{array}{l}\text { Low risk of } \\
\text { bias }\end{array}$ \\
\hline $\begin{array}{l}\text { Allocation } \\
\text { concealment }\end{array}$ & $\begin{array}{l}\text { Low risk of } \\
\text { bias }\end{array}$ & $\begin{array}{l}\text { Uncertain } \\
\text { bias risk }\end{array}$ & $\begin{array}{l}\text { Low risk of } \\
\text { bias }\end{array}$ & $\begin{array}{l}\text { Low risk of } \\
\text { bias }\end{array}$ & $\begin{array}{l}\text { Low risk of } \\
\text { bias }\end{array}$ & $\begin{array}{l}\text { Low risk of } \\
\text { bias }\end{array}$ \\
\hline $\begin{array}{l}\text { Blinding of participants } \\
\text { and professionals }\end{array}$ & $\begin{array}{l}\text { Low risk of } \\
\text { bias }\end{array}$ & $\begin{array}{l}\text { Low risk of } \\
\text { bias }\end{array}$ & $\begin{array}{l}\text { Low risk of } \\
\text { bias }\end{array}$ & $\begin{array}{l}\text { Low risk of } \\
\text { bias }\end{array}$ & $\begin{array}{l}\text { Low risk of } \\
\text { bias }\end{array}$ & $\begin{array}{l}\text { Low risk of } \\
\text { bias }\end{array}$ \\
\hline $\begin{array}{l}\text { Blinding of outcome } \\
\text { evaluators }\end{array}$ & $\begin{array}{l}\text { High risk of } \\
\text { bias }\end{array}$ & $\begin{array}{l}\text { Uncertain } \\
\text { bias risk }\end{array}$ & $\begin{array}{l}\text { Uncertain } \\
\text { bias risk }\end{array}$ & $\begin{array}{l}\text { Low risk of } \\
\text { bias }\end{array}$ & $\begin{array}{l}\text { Low risk of } \\
\text { bias }\end{array}$ & $\begin{array}{l}\text { Low risk of } \\
\text { bias }\end{array}$ \\
\hline Incomplete outcomes & $\begin{array}{l}\text { Low risk of } \\
\text { bias }\end{array}$ & $\begin{array}{l}\text { Low risk of } \\
\text { bias }\end{array}$ & $\begin{array}{l}\text { High risk of } \\
\text { bias }\end{array}$ & $\begin{array}{l}\text { Low risk of } \\
\text { bias }\end{array}$ & $\begin{array}{l}\text { High risk of } \\
\text { bias }\end{array}$ & $\begin{array}{l}\text { Low risk of } \\
\text { bias }\end{array}$ \\
\hline $\begin{array}{l}\text { Selective outcome } \\
\text { report }\end{array}$ & $\begin{array}{l}\text { Uncertain } \\
\text { bias risk }\end{array}$ & $\begin{array}{l}\text { Uncertain } \\
\text { bias risk }\end{array}$ & $\begin{array}{l}\text { Uncertain } \\
\text { bias risk }\end{array}$ & $\begin{array}{l}\text { Uncertain } \\
\text { bias risk }\end{array}$ & $\begin{array}{l}\text { Uncertain } \\
\text { bias risk }\end{array}$ & $\begin{array}{l}\text { Uncertain } \\
\text { bias risk }\end{array}$ \\
\hline Other sources of bias & $\begin{array}{l}\text { High risk of } \\
\text { bias }\end{array}$ & $\begin{array}{l}\text { Low risk of } \\
\text { bias }\end{array}$ & $\begin{array}{l}\text { High risk of } \\
\text { bias }\end{array}$ & $\begin{array}{l}\text { Uncertain } \\
\text { bias risk }\end{array}$ & $\begin{array}{l}\text { Uncertain } \\
\text { bias risk }\end{array}$ & $\begin{array}{l}\text { High risk of } \\
\text { bias }\end{array}$ \\
\hline \multicolumn{7}{|c|}{ Jadad scale } \\
\hline Variables & Hansen et al. ${ }^{9}$ & Marsh et al. ${ }^{10}$ & Alavi et al. ${ }^{11}$ & $\begin{array}{c}\text { Kjaergaard } \\
\text { et al. }{ }^{12}\end{array}$ & $\begin{array}{l}\text { Omidian } \\
\text { et al. }{ }^{13}\end{array}$ & $\begin{array}{l}\text { Zheng } \\
\text { et al. }{ }^{14}\end{array}$ \\
\hline $\begin{array}{l}\text { Was the study } \\
\text { described as } \\
\text { randomized? }\end{array}$ & Yes & Yes & Yes & Yes & Yes & Yes \\
\hline $\begin{array}{l}\text { Has randomization } \\
\text { been described and is } \\
\text { it adequate? }\end{array}$ & Yes & Yes & Yes & Yes & Yes & Yes \\
\hline $\begin{array}{l}\text { Were there any } \\
\text { comparisons between } \\
\text { the results? }\end{array}$ & Yes & Yes & Yes & Yes & Yes & Yes \\
\hline $\begin{array}{l}\text { Have comparisons } \\
\text { and results been } \\
\text { described and are they } \\
\text { adequate? }\end{array}$ & Yes & Yes & Yes & Yes & Yes & Yes \\
\hline $\begin{array}{l}\text { Have losses and } \\
\text { exclusions been } \\
\text { described? }\end{array}$ & Yes & Yes & Yes & Yes & Yes & Yes \\
\hline Total & 5 & 5 & 5 & 5 & 5 & 5 \\
\hline
\end{tabular}

results in the study may be related to the small number of participants, low concentrations of vitamin D supplementation, and the short period of the study.

Alavi et al. ${ }^{11}$ randomly assigned eligible participants to receive vitamin $D(n=40)$ or placebo $(n=40)$ for 8 weeks. The vitamin D group received 50,000 units of vitamin D3 weekly for 8 weeks at mealtime, and the control participants received a placebo weekly at the same time. All patients had vitamin $\mathrm{D}$ deficiency (vitamin $\mathrm{D}$ concentration of less than 30 $\mathrm{ng} / \mathrm{mL}$ ) before the intervention. The mean baseline $25(\mathrm{OH}) \mathrm{D} 3$ concentration was $22.57 \pm 6.2 \mathrm{ng} / \mathrm{mL}$ in the vitamin $\mathrm{D}$ group and $21.2 \pm 5.8 \mathrm{ng} / \mathrm{mL}$ in the placebo group $(\mathrm{p}=0.16)$. Vitamin $\mathrm{D}$ increased to $43.48 \pm 9.5 \mathrm{ng} / \mathrm{mL}$ in the vitamin $\mathrm{D}$ group and $25.9 \pm 15.3 \mathrm{ng} / \mathrm{mL}$ in the placebo group. Both groups showed a significant increase in vitamin $\mathrm{D}$ concentration, although the increase was approximately fourfold greater in the vitamin D group. After the intervention, it was observed that vitamin D supplementation was effective in reducing depression scores in people aged 60 years or older. The results of the study may have been positive, as all participants had vitamin $\mathrm{D}$ deficiency 
Table 2. Synthesis of studies evaluated regarding the effect of vitamin D supplementation in aiding the treatment of depression.

\begin{tabular}{|c|c|c|c|c|}
\hline Authors & Sample & Variables analyzed & Intervention & Outcome \\
\hline $\begin{array}{l}\text { Hansen } \\
\text { et al. }{ }^{9}\end{array}$ & $n=62$ & $\begin{array}{l}\text { - To examine whether vitamin D3 } \\
\text { supplementation in patients with } \\
\text { depression would result in improved } \\
\text { disease activity. } \\
\text { - Assessment instrument: International } \\
\text { Classification of Diseases (CID-10) } \\
\text { (F32.X). }\end{array}$ & $\begin{array}{l}\text { - Randomization: } \\
\text { 2,800 IU of vitamin } \\
\text { D3 or placebo. } \\
\text { - Duration: } 12 \\
\text { weeks. }\end{array}$ & $\begin{array}{l}\text { - No significant reductions } \\
\text { in depression scores were } \\
\text { found. }\end{array}$ \\
\hline $\begin{array}{l}\text { Marsh } \\
\text { et al. }{ }^{10}\end{array}$ & $n=33$ & $\begin{array}{l}\text { - To examine improvements after vitamin } \\
\text { D3 supplementation in bipolar depression } \\
\text { activity. } \\
\text { - Reduction in mood elevation or anxiety } \\
\text { symptoms. } \\
\text { - Assessment instrument: Hamilton } \\
\text { Anxiety Rating Scale, Young Mania Rating } \\
\text { Scale. }\end{array}$ & $\begin{array}{l}\text { - Randomization: } \\
\text { 5,000 IU vitamin } \\
\text { D3 or placebo. } \\
\text { - Duration: } 12 \\
\text { weeks. }\end{array}$ & $\begin{array}{l}\text { - There was no significant } \\
\text { reduction in depressive } \\
\text { symptoms. } \\
\text { - Vitamin D supplementation } \\
\text { did not improve reduction } \\
\text { in mood elevation or anxiety } \\
\text { symptoms. }\end{array}$ \\
\hline $\begin{array}{l}\text { Alavi } \\
\text { et al. }{ }^{11}\end{array}$ & $n=78$ & $\begin{array}{l}\text { - To examine the effect of D3 } \\
\text { supplementation in the treatment of } \\
\text { depression in the elderly population. } \\
\text { - Assessment tool: Geriatric } \\
\text { Depression Scale-15 questionnaire and } \\
25 \text {-hydroxyvitamin D3 to assess the level } \\
\text { of depression. }\end{array}$ & $\begin{array}{l}\text { - Randomization: } \\
\text { 50,000 IU vitamin } \\
\text { D3 or placebo. } \\
\text { - Duration: } 8 \\
\text { weeks. }\end{array}$ & $\begin{array}{l}\text { - Vitamin D supplementation } \\
\text { can improve depression } \\
\text { scores in people aged } 60 \\
\text { years and older. }\end{array}$ \\
\hline $\begin{array}{l}\text { Kjaergaard } \\
\text { et al. }{ }^{12}\end{array}$ & $n=344$ & $\begin{array}{l}\text { - To examine improvements after vitamin } \\
\text { D3 supplementation in patients with low } \\
\text { serum levels of 25-hydroxyvitamin D. } \\
\text { - Low and high serum levels of } \\
\text { 25-hydroxyvitamin D. } \\
\text { - Assessment instrument: Beck } \\
\text { Depression Inventory, Hospital Anxiety } \\
\text { and Depression Scale, Seasonal Pattern } \\
\text { Rating Scale, and Montgomery-Åsberg } \\
\text { Depression Rating Scale. }\end{array}$ & $\begin{array}{l}\text { - Randomization: } \\
40,000 \text { IU vitamin } \\
\text { D3 or placebo. } \\
\text { - Duration: } 6 \\
\text { months. }\end{array}$ & $\begin{array}{l}\text { - No significant effect of } \\
\text { vitamin D supplementation } \\
\text { was found on depressive } \\
\text { symptom scores. } \\
\text { - Low serum } \\
25 \text {-hydroxyvitamin D } \\
\text { levels are associated with } \\
\text { depressive symptoms, but } \\
\text { no effect was found with } \\
\text { vitamin D supplementation. }\end{array}$ \\
\hline $\begin{array}{l}\text { Omidian } \\
\text { et al. }{ }^{13}\end{array}$ & $n=68$ & $\begin{array}{l}\text { - To examine the effect of vitamin D3 } \\
\text { supplementation in type } 2 \text { diabetes } \\
\text { mellitus patients with depressive } \\
\text { symptoms. } \\
\text { - Assessment instrument: Beck Depression } \\
\text { Inventory-II (BDI-II-PERSIAN). }\end{array}$ & $\begin{array}{l}\text { - Randomização: } \\
4,000 \text { IU vitamin } \\
\text { D3 or placebo. } \\
\text { - Duration: } 12 \\
\text { weeks. }\end{array}$ & $\begin{array}{l}\text { - Vitamin D supplementation } \\
\text { in diabetes mellitus type } 2 \\
\text { patients may protect these } \\
\text { patients against the onset of } \\
\text { major depressive disorder. }\end{array}$ \\
\hline $\begin{array}{l}\text { Zheng } \\
\text { et al. }{ }^{14}\end{array}$ & $n=413$ & $\begin{array}{l}\text { - To examine the effect of vitamin D3 } \\
\text { supplementation in patients with knee } \\
\text { osteoarthritis with depressive symptoms. } \\
\text { - Assessment instrument: Patient Health } \\
\text { Questionnaire (PHQ-9, 0-27). }\end{array}$ & $\begin{array}{l}\text { - Randomization: } \\
\text { 50,000 IU vitamin } \\
\text { D3 or placebo. } \\
\text { - Duration: } 8 \\
\text { weeks. }\end{array}$ & $\begin{array}{l}\text { - Vitamin D supplementation } \\
\text { can improve depression } \\
\text { scores in people aged } 60 \\
\text { years and older. }\end{array}$ \\
\hline
\end{tabular}

before the intervention, and the supplemented dose was higher than in other studies.

Kjærgaard et al. ${ }^{12}$ studied participants with low and high serum $25(\mathrm{OH}) \mathrm{D}$ concentrations and a randomized clinical trial comparing placebo or 40,000 IU vitamin D supplementation for 6 months. In this intervention study, there was no significant effect of high-dose vitamin $\mathrm{D}$ on depressive symptom scores.
The study had some limitations that may have contributed to its negative results, such as a short study period, distribution of participants in groups, and the exclusion of participants with high scores for depression from the intervention. Consequently, most participants had no or only mild depressive symptoms. This may have influenced the results, as participants who were not sick were more likely to respond to the placebo. 
In a study by Omidian et al. ${ }^{13}$, randomized type 2 diabetes mellitus patients with depressive symptoms were divided into two groups to receive 4,000 IU vitamin D or placebo. The results of this study showed that vitamin D supplementation is effective in improving depressive symptoms in patients with type 2 diabetes and mild-to-moderate depressive symptoms. Vitamin D supplements significantly improve depressive symptoms, and they also significantly decrease $\mathrm{HbA1c}$, insulin, and TG concentrations in diabetic patients with vitamin $\mathrm{D}$ deficiency. A suggested mechanism for this effect may be related to vitamin $\mathrm{D}$ and insulin secretion, as vitamin $\mathrm{D}$ facilitates the release of insulin from beta-cells.

Zheng et al. ${ }^{14}$ studied randomized patients to verify the effect of vitamin $\mathrm{D}$ supplementation on depressive symptoms in patients with knee osteoarthritis (OA). The participants were randomized in a 1:1 ratio to receive a 50,000 IU vitamin D3 oral capsule or placebo monthly for 24 months. The serum $25(\mathrm{OH})$ D concentrations increased from $43.7 \pm 11.8$ to $84.5 \pm 17.3 \mathrm{nmo-}$ $1 / \mathrm{L}$ in the vitamin $\mathrm{D}$ group and increased from $43.8 \pm 12.7$ to $50.6 \pm 17.5 \mathrm{nmol} / \mathrm{L}$ in the placebo group. The study concluded that vitamin $\mathrm{D}$ supplementation and the maintenance of vitamin D at sufficient concentrations above 24 months may have beneficial effects on depression symptoms in patients with knee $\mathrm{OA}$. The study results suggest that vitamin $\mathrm{D}$ supplementation may have a positive effect on depressive symptoms when serum vitamin D concentrations become optimal. The study hypothesized that vitamin $\mathrm{D}$ may have a neuroprotective effect on the brain when vitamin $\mathrm{D}$ deficiency is corrected.

The studies analyzed in this review show that the initial vitamin D status (deficient or normal) may have been one of the factors that most influenced the improvement of depressive symptoms in patients. In addition, the severity of depressive symptoms, sample size, age of the individuals, dose of vitamin D offered, and duration of the intervention may have contributed to the outcome of the results.

\section{CONCLUSIONS}

The results of the studies indicated that vitamin D can improve depressive symptoms; however, this improvement depends on several factors such as dose and duration of supplementation as well as the initial state of health of the patient before supplementation. We emphasize the need for more clinical studies to verify the most efficient forms of supplementation for different clinical conditions.

\section{AUTHORS" CONTRIBUTIONS}

RTM: Project administration, Conceptualization, Data curation, Formal analysis, Investigation, Methodology Writing original draft, Writing - review \& editing. LARLR: Project administration, Conceptualization, Data curation, Formal analysis, Investigation, Methodology Writing - original draft, Writing - review \& editing. LMF: Data curation, Formal analysis, Investigation, Writing - review \& editing, Supervision. JMC: Data curation, Formal analysis, Investigation, Supervision, Writing - review \& editing. LCCL: Data curation, Formal analysis, Investigation, Supervision, Writing - review \& editing. OSRF: Data curation, Formal analysis, Investigation, Supervision, Writing - review \& editing. KMGF: Data curation, Formal analysis, Investigation, Supervision, Writing review \& editing.

\section{REFERENCES}

1. World Health Organization. Depression and other common mental disorders - Global health estimates [cited on Oct, 2020]. Geneva: World Health Organization; 2017. Available from: http://apps.who.int/iris/bitstream/10665/254610/1/ WHO-MSD-MER-2017.2-eng.pdf?ua=.

2. Raposo JICC. Fatores associados à variação de peso em doentes com depressão. [dissertation]. Lisboa: Faculdade de Medicina, Universidade de Lisboa, 2010.

3. World Health Organization. Health topics: Depression [cited on Oct, 2020]. Geneva: Word Health Organization; 2012. Available from: http://www.who.int/topics/depression/en.

4. Abelha L. Depressão, uma questão de Saúde Pública. Cad Saúde Colet. 2014;22(3):223. https://doi.org/10.1590/1414$462 \times 201400030001$

5. Krishnan $V$, Nestler EJ. Linking molecules to mood: new insight into the biology of depression. Am J Psychiatry. 2010;167(11):1305-20. https://doi.org/10.1176/appi. ajp.2009.10030434
6. Parker GB, Brotchie H, Graham RK. Vitamin D and depression. J Affect Disord. 2017;208:56-61. https://doi.org/10.1016/j.jad.2016.08.082

7. Fernandes de Abreu DA, Eyles D, Feron F. Vitamin D, a neuro-immunomodulator: implications for neurodegenerative and autoimmune diseases. Psychoneuroendocrinology. 2009;34 Suppl 1:S265-77. https://doi.org/10.1016/j. psyneuen.2009.05.023

8. Ginde AA, Liu MC, Camargo Jr CA. Demographic differences and trends of vitamin D insufficiency in the US population, 1988-2004. Arch Intern Med. 2009;169(6):626-32. https:// doi.org/10.1001/archinternmed.2008.604

9. Hansen JP, Pareek M, Hvolby A, Schmedes A, Toft T, Dahl E, et al. Vitamin D3 supplementation and treatment outcomes in patients with depression (D3-vit-dep). BMC Res Notes. 2019;12(1):203. https://doi.org/10.1186/s13104-019-4218-z

10. Marsh WK, Penny JL, Rothschild AJ. Vitamin D supplementation in bipolar depression: a double blind placebo controlled trial. J Psychiatr Res. 2017;95:48-53. https://doi.org/10.1016/j.jpsychires.2017.07.021 
11. Alavi NM, Khademalhoseini S, Vakili Z, Assarian F. Effect of vitamin $D$ supplementation on depression in elderly patients: a randomized clinical trial. Clin Nutr. 2019;38(5):2065-70. https://doi.org/10.1016/j.clnu.2018.09.011

12. Kjærgaard $M$, Waterloo $K$, Wang CEA, Almås B, Figenschau $Y$, Hutchinson MS, et al. Effect of vitamin D supplement on depression scores in people with low levels of serum 25-hydroxyvitamin D: nested case - control study and randomised clinical trial. Br J Psychiatry. 2012;201(5):360-8. https://doi.org/10.1192/bjp.bp.111.104349
13. Omidian M, Mahmoudi M, Abshirini M, Eshraghian MR, Javanbakht $\mathrm{MH}$, Zarei $\mathrm{M}$., et al. Effects of vitamin $\mathrm{D}$ supplementation on depressive symptoms in type 2 diabetes mellitus patients: randomized placebo-controlled double-blind clinical trial. Diabetes Metab Syndr. 2019;13(4):2375-80. https://doi.org/10.1016/j.dsx.2019.06.011

14. Zheng S, Tu L, Cicuttini F, Han W, Zhu Z, Antony B, e tal. Effect of vitamin $D$ supplementation on depressive symptoms in patients with knee osteoarthritis. J Am Med Dir Assoc. 2019;20(12):1634-40. e1. https://doi.org/10.1016/j.jamda.2018.09.006 